\title{
JUDUL PUISI RISALAH PURNOMO
}

\section{Maulidii Nurkhoirul Bariyyah}

\author{
Universitas Nahdlatul Ulama Sidoarjo
}

\section{PENDAHULUAN}

Puisi adalah seni mengekspresikan, dengan kata-kata yang tersusun dalam ayat-ayat, gambar, fakta, pikiran, perasaan, fantasi, yang menerjemahkan pengalaman subyektif atau universal: mengolah hal; prosa dan dramatis, sopan, satiris, yang berhubung dengan dialek. Menempatkan konsep, ide dalam hal. Apa yang diekspresikan dalam karya puitis, gagasan, konsepsi, perasaan yang ditimbulkannya pada mereka yang membaca atau mendengarkannya. Puisi adalah Kemampuan, khas setiap karya seni, untuk membangkitkan kesan kuat dalam pikiran dan imajinasi: itu adalah prosa sederhana, tetapi kaya akan hal. Puisi disusun dengan Suasana penuh perasaan, sugestif: itu malam yang menyenangkan dan Hal-hal 
yang membuat seseorang kehilangan puisi, kekecewaan itu, dan mengecewakan (Hoepli, 2018).

Puisi adalah kegiatan artistik menyusun ayat, mengikuti hukum atau metrik tertentu, kebiasaan ritmis. Juga sebagai komposisi dalam ayat, biasanya cukup pendek: menulis, mengomentari hal. Puisi sebagai kekayaan inspirasi, puitis dan karakter sugestif dari sebuah karya atau bagian darinya (Coletti, 2018).

Puisi pada dasarnya memberi manfaat dan guna dengan dapat mengatakan hampir secara eksklusif, ekspresi emosi dan perasaan, di mana bentuk literatur yang diteliti dan diuraikan memberikan nilai-nilai komunikatif yang lebih luas dan lebih dalam. Ini berarti bahwa pada abad terakhir puisi telah membatasi fungsi dan realisasinya terhadap lirik, sedemikian rupa sehingga saat ini istilah lirik akhirnya mengidentifikasikan dirinya dengan puisi itu sendiri dan tidak lagi menjadi salah satu bentuk kreativitas dalam syair. Puisi dalam sejarahnya telah kehilangan banyak kekayaan kreatif dan ekspresifnya yang beragam, jadi untuk memahami puisi secara 
mendalam, mungkin tepat untuk kembali ke asalnya (Giangoia, 2006).

\section{PENULIS PUISI}

Analisis ini berupaya mengupas penyair bernama lengkap Agung Purnomo dan tumbuh di Sidoarjo. Berikut tulisan puisi beliau telah disebarkan secara luas melalui penerbit nasional, yaitu: STIEBA Madura Press, dan UNUSIDA Press. 


\section{Tabel 1. Puisi Risalah Agung Purnomo}

\begin{tabular}{|c|c|c|c|c|c|c|}
\hline No & $\begin{array}{l}\text { Judul } \\
\text { Puisi }\end{array}$ & Penulis & Penerbit & $\begin{array}{l}\text { Judul } \\
\text { buku }\end{array}$ & $\begin{array}{l}\text { Jenis } \\
\text { puisi }\end{array}$ & Tahun \\
\hline 1 & Kita & $\begin{array}{c}\text { Agung } \\
\text { Purnomo, } \\
\text { Elsa } \\
\text { Rosyidah }\end{array}$ & $\begin{array}{c}\text { STIEBA } \\
\text { Madura } \\
\text { Press }\end{array}$ & $\begin{array}{l}\text { Suweda } \\
\text { Ate }\end{array}$ & $\begin{array}{l}\text { Puisi } \\
\text { Bebas }\end{array}$ & 2019 \\
\hline 2 & $\begin{array}{l}\text { Rindu di } \\
\text { Ubun- } \\
\text { Ubun }\end{array}$ & $\begin{array}{c}\text { Agung } \\
\text { Purnomo }\end{array}$ & $\begin{array}{l}\text { STIEBA } \\
\text { Madura } \\
\text { Press }\end{array}$ & $\begin{array}{l}\text { Rassana } \\
\text { Jlantir }\end{array}$ & $\begin{array}{l}\text { Puisi } \\
\text { Bebas }\end{array}$ & 2019 \\
\hline 3 & Berpulang & $\begin{array}{c}\text { Agung } \\
\text { Purnomo }\end{array}$ & $\begin{array}{c}\text { STIEBA } \\
\text { Madura } \\
\text { Press } \\
\end{array}$ & $\begin{array}{l}\text { Syair } \\
\text { Nimala }\end{array}$ & $\begin{array}{l}\text { Puisi } \\
\text { epitaf }\end{array}$ & 2019 \\
\hline 4 & $\begin{array}{c}\text { Bapak } \\
\text { Samsuri }\end{array}$ & $\begin{array}{c}\text { Agung } \\
\text { Purnomo, } \\
\text { Nur } \\
\text { Asitah }\end{array}$ & $\begin{array}{c}\text { STIEBA } \\
\text { Madura } \\
\text { Press }\end{array}$ & $\begin{array}{l}\text { Dhalubang } \\
\text { Marta }\end{array}$ & $\begin{array}{l}\text { Puisi } \\
\text { Clerihew }\end{array}$ & 2019 \\
\hline 5 & Dua Kaki & $\begin{array}{c}\text { Agung } \\
\text { Purnomo }\end{array}$ & $\begin{array}{c}\text { UNUSIDA } \\
\text { Press }\end{array}$ & $\begin{array}{l}\text { Kidung } \\
\text { Nawala } \\
\text { (Jilid 2) }\end{array}$ & $\begin{array}{l}\text { Puisi } \\
\text { Bebas }\end{array}$ & 2018 \\
\hline 6 & Pandai & $\begin{array}{c}\text { Agung } \\
\text { Purnomo, } \\
\text { Nur } \\
\text { Asitah }\end{array}$ & $\begin{array}{c}\text { STIEBA } \\
\text { Madura } \\
\text { Press }\end{array}$ & $\begin{array}{l}\text { Tolesan } \\
\text { Aditi }\end{array}$ & $\begin{array}{l}\text { Puisi } \\
\text { Riddle }\end{array}$ & 2019 \\
\hline 7 & Cantik & $\begin{array}{l}\text { Agung } \\
\text { Purnomo, } \\
\text { Nur } \\
\text { Asitah }\end{array}$ & $\begin{array}{l}\text { STIEBA } \\
\text { Madura } \\
\text { Press }\end{array}$ & $\begin{array}{l}\text { Lembhar } \\
\text { Jiwana }\end{array}$ & $\begin{array}{l}\text { Puisi } \\
\text { Jenaka } \\
\text { Limerick }\end{array}$ & 2019 \\
\hline 8 & \#CH1 & $\begin{array}{l}\text { Agung } \\
\text { Purnomo }\end{array}$ & $\begin{array}{l}\text { UNUSIDA } \\
\text { Press }\end{array}$ & $\begin{array}{l}\text { Kidung } \\
\text { Nawala } \\
\text { (Jilid 1) }\end{array}$ & $\begin{array}{l}\text { Puisi } \\
\text { Bebas }\end{array}$ & 2018 \\
\hline 9 & Menyala & $\begin{array}{l}\text { Agung } \\
\text { Purnomo }\end{array}$ & $\begin{array}{l}\text { STIEBA } \\
\text { Madura } \\
\text { Press }\end{array}$ & $\begin{array}{l}\text { Tenta } \\
\text { Kimaya }\end{array}$ & $\begin{array}{l}\text { Puisi } \\
\text { Haiku }\end{array}$ & 2019 \\
\hline 10 & $\begin{array}{c}\text { Sepekan } \\
\text { Awal } \\
\text { Tanpamu }\end{array}$ & $\begin{array}{l}\text { Agung } \\
\text { Purnomo, } \\
\text { Nur } \\
\text { Asitah }\end{array}$ & $\begin{array}{l}\text { STIEBA } \\
\text { Madura } \\
\text { Press }\end{array}$ & $\begin{array}{l}\text { Arebhan } \\
\text { Helai }\end{array}$ & $\begin{array}{l}\text { Puisi } \\
\text { bersekuen }\end{array}$ & 2019 \\
\hline 11 & Tangisnya & $\begin{array}{l}\text { Agung } \\
\text { Purnomo, } \\
\text { Nur } \\
\text { Asitah }\end{array}$ & $\begin{array}{l}\text { STIEBA } \\
\text { Madura } \\
\text { Press }\end{array}$ & $\begin{array}{l}\text { Bhumi } \\
\text { Bawera }\end{array}$ & $\begin{array}{l}\text { Puisi } \\
\text { Naratif }\end{array}$ & 2019 \\
\hline
\end{tabular}




\section{RESENSI}

Judul-judul puisi kreasi Agung Purnomo diantaranya yakni: kita (Purnomo \& Rosyidah, 2019), rindu di ubun-ubun (Purnomo, 2019c), sepekan awal tanpamu (Purnomo \& Asitah, 2019d), \#CH1 (Purnomo, 2018a), cantik (Purnomo \& Asitah, 2019b), berpulang (Purnomo, 2019a), dua kaki (Purnomo, 2018b), bapak Samsuri (Purnomo \& Asitah, 2019a), menyala (Purnomo, 2019b), tangisnya (Purnomo \& Asitah, 2019e), dan pandai (Purnomo \& Asitah, 2019c).

Agung Purnomo telah menyusun sebelas puisi dengan gaya epitaf, clerihew, bebas, riddle, bersekuen, jenaka limerik dan haiku. Puisi diterbikan pada tahun 2018 dan tahun 2019. Beberapa puisi bagus dan enak dibaca. Namun, beberapa puisi terkesan biasa saja bagi para pembaca seni. 


\section{REFERENCES}

Coletti, il S. (2018). Poesia. Retrieved June 26, 2019, from

https://dizionari.corriere.it/dizionario_italiano/P/ poesia.shtml?refresh_ce-cp

Giangoia, R. E. (2006). La funzione della poesia nel mondo antico. Retrieved June 23, 2019, from https://bombacarta.com/2006/08/09/la-funzionedella-poesia-nel-mondo-antico/

Hoepli. (2018). Poesia. Retrieved June 21, 2019, from https://dizionari.repubblica.it/Italiano/P/poesia.ht ml?refresh_ce

Purnomo, A. (2018a). \#CH1. In Kidung Nawala (Jilid 1). Sidoarjo: UNUSIDA Press.

Purnomo, A. (2018b). Dua Kaki. In Kidung Nawala (Jilid 2). Sidoarjo: UNUSIDA Press.

Purnomo, A. (2019a). Berpulang. In Syair Nimala.

Sumenep: STIEBA Madura Press.

Purnomo, A. (2019b). Menyala. In Tenta Kimaya. Sumenep: STIEBA Madura Press.

Purnomo, A. (2019c). Rindu di Ubun-Ubun. In

Rassana Jlantir. Sumenep: STIEBA Madura Press.

Purnomo, A., \& Asitah, N. (2019a). Bapak Samsuri.

In Dhalubang Marta. Sumenep: STIEBA

Madura Press.

Purnomo, A., \& Asitah, N. (2019b). Cantik. In

Lembhar Jiwana. Sumenep: STIEBA Madura

Press.

Purnomo, A., \& Asitah, N. (2019c). Pandai. In

Tolesan Aditi. Sumenep: STIEBA Madura Press. 
Purnomo, A., \& Asitah, N. (2019d). Sepekan Awal Tanpamu. In Arebhan Helai. Sumenep: STIEBA Madura Press.

Purnomo, A., \& Asitah, N. (2019e). Tangisnya. In Bhumi Bawera. Sumenep: STIEBA Madura Press.

Purnomo, A., \& Rosyidah, E. (2019). Kita. In Suweda Ate. Sumenep: STIEBA Madura Press. 